\title{
FIKIH HAK ASASI MANUSIA Menguak Kejahatan Tindak Pidana Korporasi Trafficking
}

\author{
Oleh: \\ Miftahul Ulum ${ }^{1}$ \\ Email: miftahul_ulum2001@yahoo.com
}

\begin{abstract}
This paper discusses the corporate crime of human trafficking. ${ }^{2}$ The background used is the assessment that classifies Indonesia in third place for the handling of human trafficking by the international community. The word "Hero Exchange" may often be heard, they are the workers from Indonesia who often become victims of Human Trafficking, victims sometimes traded not only for the purpose of prostitution or other forms of sexual exploitation, but also includes other forms of exploitation, such as forced labor or services, slavery or practices similar to slavery. Various government policies are made concerning the protection of women and children, basically made relatively comprehensive policies, ranging from Basic Act 1945 and the rules below. However many government policies in tackling this problem is not followed by real action in the field and it can be concluded, the legal protection of women and children victims of human trafficking is still felt less effective. This is evident from the very rarity of severe criminal imposed by the judge against traffickers. The absence of compensation in the form of sanctions against traffickers also add to the sense of injustice padakorban trafficking who have suffered both physically, mentally, and economically.
\end{abstract}

Key words: crime, corporations, trafficking, legal efforts

1 Dosen Prodi Hukum Pidana Islam STAI Syaichona Moh. Cholil Bangkalan, Peserta Program Doktor Hukum Islam Pascasarjana UIN Sunan Ampel Surabaya.

${ }^{2}$ Perdagangan manusia adalah kejahatan serius dan pelanggaran berat terhadap hak asasi manusia. Setiap tahun, ribuan pria, wanita dan anak-anak jatuh ke tangan para pedagang, di negara mereka sendiri dan di luar negeri. Hampir setiap negara di dunia dipengaruhi oleh perdagangan, baik sebagai negara asal, transit atau tujuan bagi korban. UNODC, sebagai wali dari Konvensi PBB Menentang Kejahatan Transnasional Terorganisir (UNCTOC) dan Protokol hal tersebut, membantu dalam upaya mereka untuk melaksanakan Protokol untuk mencegah, menekan dan menghukum perdagangan orang. Perdagangan manusia atau istilah human trafficking merupakan sebuah kejahatan yang sangat sulit diberantas dan disebut-sebut oleh masyarakat internasional sebagai bentuk perbudakan masa kini dan pelanggaran terhadap hak asasi manusia. Kejahatan ini terus menerus berkembang seiring dengan kemajuan teknologi, informasi, komunikasi, dan transportasi baik nasional maupun internasional. 


\section{Pendahuluan}

Setiap warga negara sebagai hamba Allah, Tuhan Yang Maha Esa telah memiliki hak-hak dasar yang melekat dan dilestarikan, dikembangkan sesuai dengan fitrahnya, dilindungi harkat dan martabatnya, dilindungi oleh agamanya dan undang-undang yang berlaku. Undang-Undang Dasar 1945 (amandemen kedua) dalam Pasal (28 A) menyebutkan bahwa, setiap orang berhak untuk hidup dan kehidupannya.

Pasal (28 B) menyebutkan bahwa setiap anak berhak atas kelangsungan hidup, tumbuh dan berkembang, serta berhak atas perlindungan dari kekerasan dan diskriminasi. Dalam norma agama apapun dilarang dan tidak menghendaki adanya tindak kekerasan, penindasan, perbudakan, pelacuran dan semacamnya. Di dalam filosofi Islam telah diletakan dasar bagi kebebasan serta penghapusan perbudakan, karena bertentangan dengan prinsip-prinsip tauhid yang mensejajarkan makna kebebasan, kemerdekaan, kesetaraan dan penghargaan manusia terhadap manusia yang lain, bahkan terhadap makhluk lain dan alam.

Teks al-Qur'an dan al-Hadits telah banyak menyatakan tentang kewajiban manusia untuk menjaga prinsip-prinsip kemanusiaan, dan salah satu dari ayat al-Qur'an menyebutkan antara lain: "Wa laqad karramna bani adama wa hamalnahum fil-barri wal-bahri wa razaqnahum minat-tayyibati wa faddalnahum ala kasirim mimman khalaqna tafdila" yang artinya "Dan sungguh, Kami telah memuliakan anak cucu Adam, dan Kami angkut dia di darat dan di laut, dan Kami beri dia rezeki dari yang baik-baik dan Kami lebihkan mereka di atas banyak makhluk yang Kami ciptakan dengan kelebihan yang sempurna" (QS, Al-Isra' ayat 70). ${ }^{3}$

Dalam era globalisasi saat ini, transportasi baik di dalam negeri suatu negara maupun lintas negara baik transportasi dengan peralatan sederhana (perahu, sepeda, kereta kuda/sapi, dan lain-lain) maupun dengan alat transportasi dengan peralatan canggih (pesawat terbang, kapal bermesin modern dan lain-lain), menyebabkan timbulnya roda perekonomian suatu

${ }^{3}$ Departemen Agama RI. Al-Qur'an dan Terjemahannya. (Jakarta: Pustaka Amani, 2002), hlm 394. 
negara mempunyai variabel dan memungkinkan bermunculan berbagai industri barang maupun industri jasa ${ }^{4}$.

Perdagangan manusia memanfaatkan kemajuan industri jasa sebagai salah satu cara untuk mengeruk keuntungan secara terus-menerus, dan merupakan industri yang paling menguntungkan di antara berbagai kejahatan transnasional lainnya termasuk trafficking of drugs and arms.

Berbeda halnya dengan kejahatan untuk komoditi barang yang habis sekali dipakai sebagaimana narkoba, komoditi manusia dapat dibeli, dijual dan diperlakukan secara kejam dan berulang-ulang untuk meningkatkan margin keuntungan. Kejahatan ini mencari mangsa pada mereka yang lemah secara fisik, emosional atau ekonomi, mengekploitasi aspirasi dan mimpi-mimpi mereka yang tidak berdosa, dalam situasi ini maka tidak akan terjadi kekurangan calon korban. ${ }^{5}$ Tindak pidana perdagangan orang dilakukan oleh berbagai kelompok besar dan kecil, terorganisasi atau tidak, bahkan oleh anggota keluarga sekalipun. ${ }^{6}$

Terorganisasinya perdagangan orang ini merupakan bentuk sindikat yang memiliki jaringan yang sangat luas, bukan hanya antardaerah atau wilayah tetapi juga antarnegara (transnasional). Pada tahun 2017 misalnya, dikonstatir 237 kasus perdagangan perempuan yang terjadi di Propinsi Kepulauan Riau, di Pulau Batam 162 kasus, di Tanjung Balai Karimun 49 kasus dan di Pulau Bintan 26 kasus, ${ }^{7}$ di Batam dan Tanjung Balai Karimun selama ini ditengarai (di samping beberapa daerah lainnya) sebagai jalur dan tempat perdangan perempuan ke luar negeri. PSK (Pekerja Seks Komersial) di Propinsi Kepulauan Riau mengalami trend naik sampai mencapai 6.288 orang dan $25 \%$ nya PSK tersebut di bawah umur. ${ }^{8}$ Disamping propinsi lain di Indonesia beberapa daerah ditengarai sebagai

4 Nugroho, Susanti, Adi, Gambaran Umum Tentang Manusia/Trafficking In Person, Ceramah di Hotel Quality Makassar, tanggal 2 Juli 2017.

5 Nugroho, Susanti, Adi, Gambaran Umum Tentang Manusia/Trafficking In Person, Ceramah di Hotel Quality Makassar, tanggal 2 Juli 2017.

${ }^{6}$ IOM Indonesia, Fenomena Trafiking Manusia dan Konteks Hukum Internasional (Jakata: IOM Press, 2017), hlm 11.

${ }^{7}$ Ibid

${ }^{8}$ GATRA, Edisi no. 30 tanggal 7-13 Juni 2017. 
jalur transit seperti: Medan, Jakarta, Solo, Surabaya, Denpasar, Makassar, Entikong, Nunukan dan daerah lain. ${ }^{9}$

Berdasarkan hal yang telah diuraikan di atas, dan melihat fenomena perdagangan orang di Indonesia yang saat ini sudah sangat memprihatinkan dan menimbulkan kesedihan yang mendalam. Hal itu bukan saja akan berbahaya untuk diri sendiri (pelaku dan korban), akan tetapi juga bisa membahayakan kelangsungan hidup bangsa di masa mendatang ${ }^{10}$. Dalam tulisan ini penulis membatasi masalah atau ruang lingkup kejahatan tindak pidana korporasi trafficking, dengan apa yang dimaksud tindak pidana perdangan orang dan upaya pencegahannya secara yuridis.

\section{Pembahasan}

Indonesia adalah negara di kawasan Asia yang letaknya strategis dan merupakan negara dengan 2/3 daerahnya merupakan lautan. Daratannya kaya akan sumber daya mineral dan rempah-rempah, menjadikan Indonesia pada waktu lampau sebagai daerah jajahan yang sangat potensial. Datangnya para penjajah telah merugikan rakyat pada waktu itu baik secara moril dan material semuanya membekas tidak terkecuali trafficking.

Sejarah trafficking di Indonesia lebih banyak memakan korban perempuan dan anak-anak. Di Indonesia hal ini bukanlah sesuatu yang baru. Sejarah menyatakan bahwa permasalahan ini sudah menjadi pusat perhatian sejak penjajahan kolonial Belanda di Indonesia. Dalam sebuah Kongres Perikatan Perkumpulan Perempuan Indonesia (PPPI) di tahun 1932, trafficking telah menjadi salah satu pokok pembahasan dalam forum tersebut. Kongres ini merumuskan rekomendasi tentang perdagangan perempuan dan anak yang diyakini terkait langsung dengan persoalan kemiskinan yang diemban oleh masyarakat kolonial. ${ }^{11}$

${ }^{9}$ IOM dan Koalisi Perempuan Indonesia, Trafficking Manusia ( Jakarta: IOM Press, 2017), hlm 15.

${ }^{10}$ Ibid

${ }^{11}$ Ibid 
PPPI berkeyakinan ada hubungan yang signifikan antara persoalan perdagangan perempuan dan pelacuran dengan masalah kemiskinan rakyat,yang pada saat itu hidup dalam belitan hutang serta kondisi kerja yang buruk bagi buruh perempuan. Satu hal yang tak terlupakan adalah sejarah sedih perempuan Indonesia yang menjadi Jugun Ianfu yang menjadi objek seksual oleh tentara Jepang pada Perang Dunia II dan hal ini jelas merupakan tindakan trafficking in women and children atas nama perbudakan seksual untuk tujuan perang. Dari hal tersebut dapat dilihat bahwa permasalahan trafficking di Indonesia, telah ada sejak berdirinya negara ini.

Dari perspektif sejarah, masalah perdagangan perempuan dan anak merupakan masalah publik yang berjalan seiring dengan pembentukan bangsa Indonesia,dan hingga saat ini pun praktik human trafficking masih ada di Indonesia dalam warna yang berbeda, yaitu berkedok sebagai Tenaga Kerja Indonesia (TKI) yang tidak sedikit dari mereka menjadi korban perdagangan manusia di luar negri. ${ }^{12}$

\section{Tindak Pidana Perdangan Orang}

Apa itu human trafficking? Trafficking merupkan konsep dinamis dengan wujud yang berubah dari waktu ke waktu, sesuai dengan perkembangan ekonomi, sosial, dan politik. Hingga saat ini belum ada definisi trafficking yang disepakati secara internasional, sehingga banyak perdebatan tentang definisi yang paling tepat tentang fenomena kompleks yang di sebut trafficking.

Namun PBB dalam Sidang Umum-nya pada tahun 1994 mendefinisikan trafficking sebagai berikut: "pemindahan orang melewati batas nasional dan internasional secara gelap dan melanggar hukum, terutama dari negara berkembang dan dari negara dalam transisi ekonomi dengan tujuan memaksa perempuan dan anak perempuan masuk dalam situasi penindasan dan eksploitasi secara seksual dan ekonomi, sebagaimana juga tindakan ilegal lainnya yang berhubungan dengan perdagangan perempuan seperti pekerja paksa 
domestik, kawin palsu, pekerja gelap dan adopsi palsu demi kepentingan perekrut, pedagang dan sindikasi kejahatan"

Jika diterjemahkan secara bebas trafficking dapat berarti pergerakan atau perpindahan orang secara rahasia dan terlarang dengan melintasi perbatasan wilayah (lokasi) dengan tujuan akhir untuk memaksa orangorang tersebut masuk ke dalam situasi yang secara seksual atau ekonomi bersifat menekan dan eksploitatif dan memberikan keuntungan bagi para perekrut, trafficker, dan sindikat kejahatan.

Definisi perdagangan orang pertama kali dikemukakan pada tahun 2000, ketika Majelis Umum Perserikatan Bangsa-Bangsa (MU PBB), menggunakan protokol untuk mencegah, menekan dan menghukum perdagangan atas manusia, khususnya kaum perempuan dan anak-anak yang akhirnya terkenal dengan sebutan "Protocol Palermo". Protokol ini merupakan sebuah perjanjian yang merupakan perangkat hukum yang mengikat dan menciptakan kewajiban bagi semua negara yang meratifikasinya atau menyetujuinya. ${ }^{13}$

Definisi perdagangan orang menurut Protokol Palermo tertuang di dalam Pasal (3) ${ }^{14}$ yang berbunyi:

a. Perdagangan orang yang dilakukan oleh orang lain, berarti perekrutan, pengiriman ke suatu tempat, pemindahan, penampungan atau penerimaan melalui ancaman, atau pemaksaan dengan kekerasan lain, penculikan, penipuan, penganiayaan, penjualan, atau tindakan penyewaan untuk mendapat keuntungan atau pembayaran tertentu untuk tujuan eksploitasi. Eksploitasi setidaknya mencakup eksploitasi melalui pelacuran, melalui bentuk lain eksploitasi seksual, melalui perbudakan, melalui, praktik-praktik serupa perbudakan, melalui penghambaan atau melalui pemindahan organ tubuhnya .

b. Persetujuan korban perdagangan orang atas eksploitasi yang dimaksud pada pasal (3) sub (a), pasal ini menjadi tidak relevan apabila digunakan sarana yang dimaksud pada sub (a).

\footnotetext{
${ }^{13}$ Ibid

${ }^{14}$ IOM, Combating Trafficking in Person in Indonesia (Jakarta: IOM Press, 2017), hlm 4.
} 
c. Perekrutan, pengangkutan, pemindahan, penampungan atau penerimaan seorang anak untuk maksud eksploitasi dianggap sebagai "perdagangan orang" meskipun apabila hal ini tidak mencakup salah satu sarana yang termaktub pada sub (a) pasal ini.

d. "Anak" berarti seseorang yang masih di bawah umur 18 (delapan belas) tahun. ${ }^{15}$

Berpokok pangkal dari definisi tersebut di atas dalam Pasal (3) sub (a), maka dapat dilihat unsur pokoknya, yaitu:

1) Proses: terdiri dari perekrutan, pengangkutan, pemindahan, penampungan atau penerimaan orang.

2) Cara: ancaman, atau paksaan dengan kekerasan atau dengan cara-cara kekerasan lain, penculikan, penipuan, penyiksaan/penganiayaan, pemberian atau penerimaan pembayaran tertentu untuk persetujuan atau mengendalikan orang lain.

3) Tujuan: eksploitasi (setidaknya melalui pelacuran, melalui bentuk lain eksploitasi seksual, melalui kerja paksa atau memberikan pelayanan paksa, melalui perbudakan, melalui praktik-praktik serupa perbudakan, melalui penghambaan atau melalui pemindahan organ tubuh). ${ }^{16}$

Selanjutnya dasar pemikiran dikeluarkannya "Protokol Palermo" adalah:

1) Memperkenalkan definisi internasional pertama tentang perdagangan orang.

2) Menjabarkan suatu pendekatan yang komprehensif untuk menunjukkan kejahatan perdagangan orang.

3) Menggariskan dan menyarankan upaya-upaya kooperasi antarnegara guna memerangi perdagangan orang dan melindungi serta melayani korban. ${ }^{17}$

Di Indonesia Dewan Perwakilan Rakyat Republik Indonesia (DPR RI) dalam Rapat Paripurna Terbuka tanggal 20 Maret 2007 telah menyetujui Rancangan Undang-Undang (RUU) tentang Pemberantasan Tindak Pidana

\footnotetext{
${ }^{15}$ Ibid

${ }^{16} \mathrm{IOM}, \mathrm{Ibid}, 5$

${ }^{17}$ IOM, Ibid , 6.
} 
Perdagangan Orang (PTPPO) untuk disahkan menjadi Undang-Undang dengan Nomor 21 tahun 2007, Lembaran Negara Republik Indonesia Nomor 4720. Undang-Undang ini merupakan perwujudan dari komitmen Indonesia untuk melaksanakan Protokol PBB tahun 2000 tersebut dan telah diundangkan pada tanggal 19 April 2007.

Sebagai perbandingan dengan protokol Palermo, maka definisi perdagangan orang menurut Pasal (1) ayat (1) Undang-Undang Nomor 21 Tahun 2007 adalah: "tindakan perekrutan, pengangkutan, penampungan, pengiriman, pemindahan atau penerimaan seseorang dengan ancaman kekerasan, penggunaan kekerasan, penculikan, penyekapan, pemalsuan, penipuan, penyalahgunaan kekuasaan atau posisi rentan, penjeratan hutang atau memberi bayaran atau manfaat sehingga memperoleh persetujuan dari orang yang memegang kendali atas orang lain tersebut, baik yang dilakukan di dalam negara maupun antarnegara, untuk tujuan eksploitasi atau mengakibatkan orang tereksploitasi."18

Selanjutnya di dalam Pasal (1) ayat (7) Undang-Undang Nomor 21 Tahun 2007 disebutkan bahwa "eksploitasi adalah tindakan dengan atau tanpa persetujuan korban yang meliputi tidak terbatas pada pelacuran, kerja atau pelayanan paksa, perbudakan atau praktik berupa perbudakan, penindasan, pemerasan, pemanfaatan fisik, seksual, organ reproduksi, atau secara melawan hukum memindahkan atau mentransplantasi organ/atau jaringan tubuh atau memanfaatkan tenaga atau kemampuan seseorang oleh pihak lain untuk mendapatkan keuntungan baik materiil maupun immateriil".

Bertolak dari pengertian tersebut di atas, maka dapat dikembangkan beberapa unsur tindak pidana perdagangan orang, yaitu: perekrutan, pengangkutan, penampungan, pengiriman, pemindahan atau penerimaan seseorang.

Untuk modus yang digunakan, maka dapat dirinci: ${ }^{19}$ ancaman kekerasan, penggunaan kekerasan, penculikan, penyekapan, pemalsuan, penipuan, penyalahgunaan kekuasaan (a buse of power), penjeratan hutang

${ }^{18}$ Ibid.

${ }^{19}$ Ibid 
atau memberi bayaran atau manfaat walaupun memperoleh persetujuan dari orang yang memegang kendali atas orang lain.

Selanjutnya tujuan dan akibat eksploitasi manusia: eksploitasi prostitusi, eksploitasi seksual, perbudakan, kerja paksa atau pelayanan paksa, praktik serupa perbudakan, perhambaan, dan peralihan organ (removal organ) dengan atau tanpa persetujuan orang.

Sarana pengangkutan tindak pidana perdagangan orang ini bisa menggunakan metode: (1) overt (terang-terangan), identitas atau dokumen perjalanan asli atau dipalsukan atau visa palsu; (2) dan covert (sembunyi): kendaraan, kereta, perbatasan tanpa penjagaan (melalui jalan tikus, pelabuhan kecil, dan lain sebagainya) ${ }^{20}$.

Bagian terbesar korban perdagangan orang digunakan untuk tujuan eksploitasi seksual (pelacuran dan phedofhilia) serta bekerja pada tempattempat kasar degan upah rendah seperti di pelabuhan, buruh, pembantu rumah tangga dan sebagainya. ${ }^{21}$

Di pedesaan, pilihan yang acapkali dihadapi anak perempuan relatif tidak banyak, sebagian anak perempuan di pedesaan mungkin beruntung, bisa melanjutkan sekolah karena ditopang kondisi ekonomi orang tuanya yang cukup mapan. Tetapi dalam banyak kasus, anak perempuan yang sudah menginjak usia belasan tahun, mereka akan didesak orang tuanya untuk segera menikah, bekerja atau membantu orang tua menyelesaikan berbagai pekerjaan domestik di rumah.

Di Jawa Timur, beberapa daerah seputar kawasan tapal kuda dan Pulau Madura, pada akhir abad 19 dan awal abad 20, terjadi anak berusia 14-16 tahun dinikahkan dengan lelaki pilihan orang tuanya22, juga di daerah Indramayu dikenal adanya istilah "luruh duit" yaitu untuk mencari "kesugihan" (kekayaan) dengan cara pelacuran. ${ }^{23}$

20 Kementrian Koordinator Bidang Kesejahteraan Rakyat 2004, Penghapusan Perdagangan orang/trafficking in Person di Indonesia tahun 2003-2004, Jakarta, 2004, hlm 11.

${ }^{21}$ Ibid

${ }^{22}$ Nugroho, Adi, Susanti, Op Cit. 7

23 Sudrajat, Tata, "Luruh Duit", http:// anak.12.co.id/berita baru/berita.asp?id=197. 
Sebagian anak perempuan pada akhirnya lebih memilih keluar rumah, menjadi migran, mengadu nasib ke kota besar untuk mencari pekerjaan, baik dalam rangka sekedar mencari pengalaman, keluar dari tekanan psikologis di rumah, atau karena ingin mencari penghasilan sendiri layaknya orang dewasa.

Korban perdagangan manusia biasanya anak-anak, perempuan berusia muda dan belum menikah, anak korban perceraian, serta mereka yang pernah bekerja di kota-kota besar atau di luar negeri. Tetapi, korban perdagangan orang tidak hanya kaum perempuan saja tetapi juga laki-laki dan anak laki-laki. ${ }^{24}$

Melihat uraian di atas, maka korban perdagangan orang dapat menimpa, seorang perempuan, seorang laki-laki dan anak-anak (lakilaki/perempuan), disamping dikuasai secara fisik tetapi juga ada yang dimanfaatkan organ tubuhnya. ${ }^{25}$

\section{Upaya Hukum}

Ketentuan mengenai larangan perdagangan manusia pada dasarnya telah diatur dalam Kitab Undang-Undang Hukum Pidana (KUHP) Pasal (297) yang menyatakan: "perdagangan wanita dan perdagangan anak lakilaki yang belum dewasa, diancam dengan pidana penjara paling lama enam tahun", juga di dalam Pasal (324) KUHP dinyatakan: "barang siapa dengan biaya sendiri atau dengan biaya orang lain menjalankan perniagaan budak atau dengan sengaja turut serta secara langsung atau tidak langsung dalam salah satu perbuatan tersebut di atas, diancam dengan pidana penjara paling lama dua belas tahun"

Disamping di dalam KUHP, perdagangan orang juga telah diatur dalam Pasal (65) Undang-Undang Nomor 39 Tahun 1999 tentang Hak-hak Asasi Manusia, yang menyatakan: "setiap anak berhak untuk memperoleh perlindungan dari kegiatan eksploitasi dan pelecehan seksual, penculikan,

24 IOM, Manual Pemulangan, Pemulihan dan Reintegrasi Korban Trafiking (Jakarta: IOM Press, 2017), hlm 2.

${ }^{25}$ Ibid 
perdagangan anak, serta dari berbagai bentuk penyalahgunaan narkotika, psikotropika, dan zat adiktif lainnya".

Selain itu juga di dalam Undang-Undang Nomor 23 Tahun 2002 tentang Perlindungan Anak telah mengatur tentang perdagangan anak dan eksploitasi seksual terhadap anak sebagaimana diatur dalam Pasal (83) dan Pasal (88).

Di dalam Pasal (83) Undang-Undang Nomor 23 Tahun 2002 tentang Perlindungan Anak, disebutkan bahwa: "setiap orang yang memperdagangkan, menjual, atau menculik anak untuk diri sendiri atau untuk dijual, dipidana dengan pidana penjara paling lama 15 (lima belas) tahun dan denda paling banyak Rp.300.000.000,00 (tiga ratus juta rupiah) dan paling sedikit Rp. 60.000.000,00 (enam puluh juta rupiah), sedangkan Pasal (88) Undang-Undang Nomor 23 Tahun 2002 tentang Perlindungan Anak menyatakan: "setiap orang yang mengeksploitasi ekonomi atau seksual anak dengan maksud untuk menguntungkan diri sendiri atau orang lain, dipidana dengan pidana penjara paling lama 10 (sepuluh) tahun dan/atau denda paling banyak Rp. 200.000.000,00 (dua ratus juta rupiah).

Undang-Undang Nomor 23 Tahun 2002 tentang Perlindungan Anak, yang dalam Pasal (1) ayat (1) menyebutkan, bahwa yang dimaksud dengan anak adalah: "seseorang yang belum berusia 18 (delapan belas) tahun, termasuk anak yang masih dalam kandungan", undang-undang tersebut tidak bisa diterapkan kepada pelaku perdagangan orang yang korbannya bukan anak-anak. ${ }^{26}$

Di dalam praktik pasal-pasal pemidanaan tersebut sulit untuk diterapkan, sebagaimana prediksi pihak kepolisian, bahwa pelaku perdagangan orang seringkali terdiri dari orang-orang yang berbeda pada tahapan perdagangan orang, seperti misalnya orang yang merekrut berbeda dengan orang yang mengantar atau membawa korban. Upaya penuntutan kepada germo yang sering berlaku sebagai pelaku perdagangan orang menggunakan Pasal 333 KUHP tentang "merampas kemerdekaan seseorang" juga sulit dilakukan, karena "anak asuhnya" bersedia

${ }^{26}$ Ibid 
"memberikan" pernyataan tertulis bahwa mereka datang atas kemauan sendiri dan seijin orang tua. ${ }^{27}$

Kerancuan penafsiran mengenai "anak" di bawah umur, di dalam Pasal (45) KUHP disebut bahwa: "dalam hal penuntutan pidana terhadap orang yang belum dewasa, karena melakukan sesuatu tindak pidana sebelum umur 16 (enam) belas tahun ${ }^{28}$.

Anak adalah orang yang dalam masalah anak nakal telah mencapai 8 (delapan) tahun tetapi belum mencapai 18 (delapan belas) tahun dan belum pernah kawin, sedangkan menurut Undang-undang Nomor 23 Tahun 2002 tentang Perlindungan Anak dalam Pasal (1) ayat (1) dinyatakan: "anak adalah seseorang yang belum berusia 18 (delapan belas) tahun, termasuk anak yang masih dalam kandungan", dalam hal ini masih belum ada persamaan antara undang-undang yang satu dan undangundang yang lainnya, yang bisa berpengaruh terhadap penindakan hukum bagi pelaku perdagangan orang.

Selanjutnya dalam Pasal (297) KUHP mengenai larangan perdagangan wanita dan perdagangan anak laki-laki belum dewasa dan mengkualifikasikan tindakan tersebut sebagai suatu kejahatan yang sanksinya dinilai terlalu ringan yang tidak sebanding dengan dampak yang diderita korban akibat perdagangan orang, yakni dengan dipidana penjara paling lama enam tahun, sedangkan pada Undang-Undang Nomor 21 Tahun 2007 tentang Pemberantasan Tindak Pidana Perdagangan Orang (PTPPO) dipidana paling singkat tiga tahun dan paling lama 15 (lima belas) tahun dan pidana denda paling sedikit Rp. 120.000.000,00 (seratus dua puluh juta rupiah) dan paling banyak Rp. 600.000.000,00 (enam ratus juta rupiah), Pasal (2) ayat (1) Undang-Undang Nomor 21 Tahun 2007 tentang PTPPO menyebutkan: "jika menyebabkan korban eksploitasi tersebut menderita luka berat, terganggu jiwanya, hilangnya fungsi reproduksi, kehamilan maka ancaman pidananya ditambah $1 / 3$ dari ancaman pidana seperti tersebut di atas, dan apabila mengakibatkan matinya korban, dipidana dengan pidana penjara paling singkat 5 (lima) tahun dan paling

${ }^{27}$ Kementrian Koordinator Bidang Kesra, Op Cit, 3.

${ }^{28}$ Ibid 
lama penjara seumur hidup dan dipidana denda paling sedikit Rp. 200.000.000,00 (dua ratus juta rupiah) dan paling banyak Rp. 5.000.000.000,00 (lima milyar rupiah). ${ }^{29}$

Dalam hal tindak pidana perdagangan orang dilakukan suatu korporasi (korporasi adalah kumpulan orang dan/atau kekayaan yang terorganisasi baik merupakan badan hukum maupun bukan badan hukum)- selain pidana penjara dan denda terhadap pengurusnya juga dipidana denda dan pemberatan 3 (tiga) kali lipat dari pidana denda sebagaimana diatur dalam Pasal (2, 3 ,4, 5 dan 6) Undang-Undang Nomor 21 Tahun 2007 tentang PTPPO, dan pencabutan ijin usaha, perampasan kekayaan hasil tindak pidana pencabutan status badan hukum (Pasal (15) ayat (2) Undang-Undang Nomor 21 Tahun 2007 tentang PTPPO). ${ }^{30}$

Di samping undang-undang tersebut di atas, sebagai dasar hukum nasional untuk menindak pelaku perdagangan orang, dapat diperinci sebagai berikut.

1. Undang-Undang Dasar 1945 (Pasal 26, 28, dan 29 ayat(2) ).

2. Tap MPR Nomor 4/1999 tentang GBHN Tahun 1999.

3. Tap MPR Nomor 4/1997 tentang Kesejahteraan Anak.

4. Undang-Undang RI Nomor 3/1997 tentang Pengadilan Anak.

5. Undang-Undang RI Nomor 20/1999 tentang Ratifikasi Konvensi Nomor 138/1973 tentang usia minimum diperbolehkan bekerja.

6. Undang-Undang RI Nomor 22/1999 tentang Otonomi Daerah.

7. Undang-Undang RI Nomor $1 / 2000$ tentang HAM.

8. UU RI tahun 2000 tentang Ratifikasi Konvensi ILO RI 172 tentang pelanggaran dan tindakan segera penghapusan bentuk-bentuk pekerjaan terbuka untuk anak-anak.

9. UU RI Nomor 25/2000 tentang PROPERNAS.

10. Keppres RI Nomor 36/1990 tentang Pengesahan Konvensi Hak Anakanak (Convention the Right of Child). 
11. Keppres RI Nomor 101/2001 tentang Kedudukan, Tugas, Fungsi Kewenangan, Susunan Organisasi dan Tata Kerja Menteri Negara (Pasal 5).

12. Keppres RI Nomor 87/2002 tentang RAN Penghapusan Perdagangan (trafficking) Perempuan dan Anak.

13. Keppres RI Nomor 87/2002 tentang RAN RESKA.

14. PRIN Kapolri No.POL.5 PRIN/935/V/2003 Kekuasaan terhadap Perempuan dan Anak berpedoman kepada:

- UU Nomor 23/2002 tentang Perlindungan Anak;

- UU Nomor 23/2004 tentang Penghapusan KDRT;

- UU Nomor 39/2004 tentang Penempatan dan Perlindungan TKI.

Selanjutnya sistem pemerintahan dengan sistem otonomi daerah, maka yang telah merespon tentang perdagangan orang, dengan mengeluarkan Peraturan Daerah (Perda) adalah:

1. Sulawesi Utara, Perda No.1/2004 tentang Anti Trafficking dan SK Gubernur Nomor 130/2004 tentang Pembentukan Gugus Tugas.

2. Sumatera Utara, Perda No.5/2004 tentang Anti Trafficking.

3. Pemda Kota Damai, Riau tahap penyusunan Rencana Aksi Daerah tentang Anti Trafficking.

4. Pemda DKI Jakarta, Perda No.6/2004 tentang Ketenagakerjaan.

5. Jawa Barat SK Gubernur No.43/2004 membentuk komite penghapusan bentuk-bentuk pekerjaan terbentuk bagi anak, perdagangan dan ESKA.

6. Nusa Tenggara Timur, SK No.173/2005 tentang Pembentukan gugus tugas Rencana Aksi Nasional (RAN) penghapusan perdagangan perempuan dan anak (P3A).

7. Jawa Tengah, Kabupaten Cilacap menyusun draft Perda tentang penempatan dan perlindungan pekerja migran ke luar negeri, Kota Surakarta menyusun rencana aksi tentang P3A.

8. DI Yogyakarta, menyusun draft Perda hubungan pekerja antara pekerja rumah tangga dengan majikan.

9. Jawa Timur, SK Gubernur No. 188/2003 tentang Pembentukan Gugus Tugas P3A, PESKA dan bentuk untuk pekerjaan terburuk bagi anak. 
10. Kalamantan Barat Perda tentang PJA.

11. Kalimantan Timur, SK Gubernur No.350/2004 membentuk Koalisi Anti Trafficking.

12. Nusa Tenggara Barat, Perda No.11/2003 tentang Perlindungan dan Pembinaan Tenaga Kerja asal Indonesia.

13. Bali, SK Bupati Buleleng No.341/2005 tentang Pembentukan TIM Gugus Tugas P3A dan PESKA. (Sumber IOM/International Organization Migration di Indonesia)

Melihat ketentuan-ketentuan dan peraturan daerah yang ada tersebut di atas, maka mestinya bisa meminimalisir pelaku ataupun korban dari trafficking manusia di Indonesia, namun kenyataannya kejahatan trafficking manusia, masih marak dan sulit untuk diberantas.

Untuk itu dapat dilihat tentang data korban trafficking manusia di Indonesia (data harian Kompas). Sekitar 2,5 - 3 juta perempuan dan anak bekerja pada sektor-sektor yang rentan trafficking termasuk di antarannya kira-kira 250 (dua ratus lima puluh) ribu sampai 400 (empat ratus) ribu anak-anak korban trafficking di Indonesia.

Data perdagangan orang di Indonesia dari tahun 2013 sampai 2017 ada sedikit penurunan dari 179 kasus pada tahun 2013, 155 kasus tahun 2014, 125 kasus tahun 2015, 43 kasus tahun 2016 dan 30 kasus tahun 2017 (data mingguan Konstan).

Data tahun 2017/2018, 53 kasus telah divonis bebas, hukuman penjara minimal 6 bulan terberat 13 tahun. Rangking/peringkat tempat terjadinya traffiking: Jakarta, Surabaya, Kalimantan Barat, Sumatera Selatan, Kepulauan Riau, dan Sulawesi Selatan.

Melihat uraian di atas, maka dapat disimpulkan bahwa meskipun telah ada ketentuan dan sanksinya, namun kejahatan traffiking masih terus berlangsung, meskipun tiap tahun menunjukan penurunan kasus.

\section{Simpulan}

Perdagangan orang dapat dilihat dari beberapa unsur pokoknya yaitu melalui: proses, perekrutan, pengangkutan, penampungan, pengiriman, pemindahan atau penerimaan seseorang, dan modus yang di 
gunakan untuk melaksanakan kegiatan tersebut dengan cara, ancaman kekerasan, penggunaan kekerasan, penculikan, penyekapan, pemalsuan, penipuan, penyalah gunaan kekuasaan (a buse of power), penjeratan hutang atau memberi bayaran atau manfaat waupun memperoleh persetujuan dari orang yang memegang kendali atas orang lain. Selanjutnya tujuan dan akibat eksploitasi seksual, perbudakan, kerja paksa atau pelayanan paksa, praktik serupa perbudakan, perhambaan, peralihan organ (removal organ) atau tanpa persetujuan orang.

Dalam hal ini tidak hanya manusia yang bisa menjadi korban perdagangan orang, akan tetapi juga organ tubuh dari manusia itu sendiri, selanjutnya yang dapat menjadi korban, disamping anak-anak dan perempuan juga bisa seorang laki-laki dewasa. Pelaku tindak pidana perdagangan orang bisa secara sendiri atau perseorangan, juga bisa suatu badan hukum dan dilakukan antar lintas kota suatu negara, juga antar lintas negara.

Selanjutnya upaya hukum yang digunakan untuk mencegah, menghukum, pelaku maupun memberantas perdagangan orang yaitu dengan telah disahkan dan diundangkannya Undang-Undang Nomor 21 Tahun 2007 tentang pemberantasan tindak pidana perdagangan orang, diharapkan pada para penegak hukum khususnya hakim dapat menerapkan hukuman yang maksimal terhadap pelaku tindak pidana perdagangan orang, melindungi dan memberikan pelayanan yang maksimal kepada korban.

Penghapusan perdagangan orang terutama perempuan dan anakanak tidaklah mudah, karena jumlah masalah yang dihadapi sangat kompleks dan multidimensional. Otoritas kepentingan/pejabat yang berwenang harus membangun kerja sama dan komitmen yang berat, lugas dan tegas guna melindungi warganya dari bahaya perdagangan orang, peraturan perundangan yang memadai dan para penegak hukum yang tegas dan capable dalam menjalankan penegakan hukum, hal itu merupakan modal pokok yang harus diciptakan untuk melawan para pelaku tindak pidana perdagangan orang. 


\section{DAFTAR PUSTAKA}

Abu Bakar, Anwar. 2007. Al Qur'an dan Terjemahannya. Sinar baru Algensindo. Jakarta: Sinar Baru Al-Gesindo.

Al-Askholani, Al-Imam Al-Hafidz Ibnu Hajar. tt. Bulughul Maram Juz I, bittashih watta'lik alaih Muhammad Hamid Al-Faqi. Surabaya : Syarikah Maktabah wa-Matbaa Ahmad bin Saad bin Nabhani waAwladihi.

Departemen Agama RI. 2002. Al-Qur'an dan Terjemahannya. Jakarta: Pustaka Amani.

Irwanto, Mohammad Farid, Jeffry Anwar. 1998. Ringkasan Analisa Situasi Anak Yang Membutuhkan Perlindungan Khusus. Terjemahan oleh Agustina Hendriati. Jakarta: PKPM Atma Jaya.

Irwanto. 2001. Perdagangan Anak di Indonesia. dalam Progressia Vol. IV Juni 2001, Malang.

Irwanto, Fentiny Nugroho, Johanes Debora Imelda. 2001. Perdagangan Anak di Indonesia. Jakarta: Kantor Perburuhan International dan Jurusan kesejahteraan Sosial FISIP-UI.

International Organization For Migration (IOM). 2017. Manual Pemulangan, Pemulihan dan Reintegrasi Korban Trafficking. Jakarta: IOM Press.

Kementrian Koordinator Bidang Kesra. 2003. Penghapusan Perdagangan Orang (Trafficking in Person) di Indonesia. Jakarta.

Kerjasama Pucuk Pimpinan Fatayat NU, IOM dan The People Of Japan. 2005.Training Manual Law Enforcement Seminars Combatting Trafficking in Person in Indonesia, Jakarta, 2005.

Kerjasama Pucuk Pimpinan Fatayat NU, IOM dan The People Of Japan. 2017. Panduan Motivator Waspada Trafficking Manusia. Jakarta, 2017. 
Koalisi Perempuan Indonesia dan IOM. 2017. Waspadai Trafiking di Sekitar Kita. Jakarta: IOM Press.

Moeljatno. 2001. KUHP. Jakarta: Bumi Aksara.

Parawansa, Khofifah Indar. 2000. Pemberdayaan Perempuan Indonesia Dalam Pembangunan di Abad 21 Dalam Rangka Hari Kependudukan Dunia. Saving Women Lives. Jakarta: Kantor Kementrian Negara Transmigrasi dan Kependudukan.

Rifa'i, Mohammad. 1978. Fiqih Islam Lengkap. Semarang: Toha Putra.

Sudrajat, Tata, Luruh Duit. http ://anak.12 co.id/berita baru/berita.asp? id $=197$.

Undang-Undang Dasar 1945 dan Perubahannya. 2004. Jakarta: Kawan Pustaka.

Undang-Undang RI Nomor 23 Tahun 2002 tentang Perlindungan Anak. 2003. Jakarta: Departemen Sosial.

Undang-Undang RI Nomor 39 Tahun 2004 tentang Hak Asasi Manusia. Jakarta: Indonesia Legal Center Publishing.

Undang-Undang RI Nomor 21 Tahun 2007 tentang Pemberantasan Tindak Pidana Perdagangan Orang. Bandung: Citra Umbara. 